\title{
Chapter \#8
}

\section{TRANSGENERATIONAL EFFECT OF ATTACHMENT What was I given as a child, what do I share with my partner and what do I give to my newborn?}

\author{
Katarína Greškovičová \& Kristína Mrázková \\ Institute of Applied Psychology, Faculty of Social and Economic Sciences, Comenius University in \\ Bratislava, Slovakia
}

\begin{abstract}
Attachment theory describes functioning through internal working models that guide expectations and behaviours in the relationships. Our aim was to analyze transgenerational effect of attachment. We also wanted to map the attachment with respect to bonding and remembered attachment. Our sample consisted of 100 participants (26 men and 74 women) between 21 and 46 years from non-clinical population that were shortly postpartum. They filled 3 self-administered questionnaires: Egna Minnen Betraffande Uppfostran- short form (My memories of upbringing, sEMBU), The Experiences in Close Relationships-Revised (ECR-R), and The Mother-Infant Bonding Questionnaire (MIBQ). Emotional warmth shown by mother had prediction power to attachment in close relationship (avoidance in 9\% and anxiety in 5\%) which in turns correlated with the wish for physical contact with own infant (desire to touch or hold the infant). Furthermore, emotional warmth together with rejection by mother were predictors of acceptance of own parent's role in bonding in $8 \%$ and $5 \%$ respectively. We see several limits among which self-reported instruments, new questionnaire MIBQ, age range and smaller sample of men. Nevertheless, we consider our research to be important in slightly clarifying an importance of remembered emotional warmth of mother in functioning in actual relationships (attachment avoidance and anxiety) and in bonding (acceptance of own parent's role).
\end{abstract}

Keywords: bonding, attachment, parent, newborn, transgenerational transmission, transgenerational effect.

\section{INTRODUCTION}

Attachment stems from child's innate need to attach to a primary person (Bowlby, 2010). From a life span perspective (Hennelová, 2014), attachment behaviour manifests all one's life and its main goal- feeling of security- is constant (Bowlby, 2010). Only the needs of the attachment, the event of its triggering, the forms of acquiring a closeness and attachment figures are subjects to change (Mikulincer \& Shaver, 2007). Attachment runs on "internal working models" that store scenes with attachment situations and they create interpretation filters that affect behaviour, thinking, and perception in attachment relationships (Bretherton \& Munholland, 2008).

Thanks to internal working models, attachment types are resistant to change. Researches have reported that the consistency rate was minimum $70 \%$ (Crowell, Treboux, \& Waters, 2002; Hamilton, 2000; Sundin, Wiberg, \& Eklöf, 2002; Waters, Merrick, Treboux, Crowell, \& Albersheim, 2000). But the internal working models of attachment can shatter and break when an adversity happens. When children experienced the loss of a parent, divorce of the parents, life-threatening illness, psychiatric disease, or sexual abuse 
by a family member, $44 \%$ of them changed the attachment type in the adulthood (Waters et al., 2000; Waters \& Cummings, 2000).

An absorbing and explanatory concept of attachment functioning in adulthood is the one delineated by Mikulincer and Shaver (2008). It consists of three modules. The first assesses the degree of threat, the second one focuses on the availability, sensitivity, and responses of the attachment figure, and the third one on the possibilities of approaching to the attachment figure. There are two strategies how to approach the attachment figure- hyperactivation and deactivation, that are related to emotion regulation and behavioral attachment system. Hyperactivating strategies lead to the formation of an anxious relationship (indecisive or resistant) and excessive sensitivity to threat, while deactivating strategies induced by relationship figure rejection lead to avoidant relationship and rejection of the attachment figure. Combination of these hyper/deactivating strategies gives four types or styles of attachment and they are recognized both in the childhood and the adulthood (Bartholomew \& Horowitz, 1991; Brennan, Clark, \& Shaver, 1998). We differentiate secure style and insecure style that namely includes three subcategories- insecure-dismissive (avoidant), insecure-preoccupied (anxious) and insecure-unresolved. In the research, both approaches- dimensions and typology- are used to explore attachment manifestations.

Adult attachment has been traditionally associated with partnership, marriage, and parenthood. Insecurely attached individuals differed in regulating their emotions- individuals higher in attachment anxiety were more likely to control their emotions by using others and by relying on them while those higher in avoidance were less likely to do so, tended to distance themselves and suppressed their feelings (Pietromonaco, Barrett, \& Powers, 2006). Moreover, partners that possessed positive perceptions about their partner were more satisfied with the relationship (Cobb, Davila, \& Bradbury, 2001). Attachment anxiety was in positive relation with relational dissatisfaction (Birnbaum, 2016). Furthermore, research also confirms the connection between attachment styles and love styles, where insecure attachment was associated with relationship problems (Mikulincer \& Shaver, 2007). Anxious and avoidant individuals experienced lower sexual satisfactions (Birnbaum, Reis, Mikulincer, Gillath, \& Orpaz, 2006; Butzer \& Campbell, 2018). Attachment avoidance was in strong negative relationship with relation intimacy, passion, and commitment (Greskovičova \& Sakačová, 2019).

When transitioning to parenthood, $83 \%$ of individuals kept their attachment style (Crowell et al., 2002). Additionally, insecure individuals feel uncertain about their parenthood abilities. Insecure-dismissive individuals were more uncertain about their relationships toward young children and about the possibility of becoming a parent. Avoidant mothers did not even feel so close to their children than securely attachment mothers. (Rholes, Simpson, \& Blakely, 1995). Insecure-dismissive and preoccupied individuals kept more negative models of parenthood and parent-child relationships than securely attached individuals (Rholes, Simpson, Blakely, Lanigan, \& Allen, 1997). Insecure-dismissive individuals perceived themselves as well as their parents negatively and they did not feel like having kids. On the other hand, insecure-preoccupied individuals wanted to have kids very much, but they also had a negative perception of their parents.

One of the vexing questions in attachment research dedicates to intergenerational transmission of attachment, and especially on its effect size (Verhage et al., 2016). Intergenerational/transgenerational transmission involves two or three objects (generations) of research sample (grandparents, parents, children) and the results confirmed concordance of attachment styles (Behrens, Haltigan, \& Bahm, 2016; Bretherton \& Munholland, 2008; Feeney \& Woodhouse, 2016). But what about having just one object of research? Let's 
illuminate this transmission within one person. We call this transgenerational effect of attachment (what was I given- remembered attachment, what do I share with my partner- attachment in close relationships, what do I give to my newborn- bonding) and there are researches that have partially devoted to this effect.

There were several weak to moderate relationships between remembered attachment and attachment in close relationships (Priel \& Besser, 2000; Rozvadský Gugová, Heretik, \& Hajdúk, 2014). Furthermore, researchers provide invincible evidence that parent representations are empirically linked to parenting (Feeney \& Woodhouse, 2016; Van Ijzendoorn, 1995) with a moderate relationship between parent attachment representations and his/her sensitivity (Feeney \& Woodhouse, 2016). Remembered attachment with mother combined with anxiety, parental competence, received support, fetal attachment, marital status explained $41 \%$ of variance of early postpartum relationship between mother and the baby (Mercer \& Ferkehch, 1990). Furthermore, this relationship between mother and the baby was associated with mother's own remembered attachment (Behrendt et al., 2016). When talking about relationship towards own newborn, we take parent-to-infant relationship or bonding to be our conceptual frame. Bonding is a type of emotional relationship that is unique, specific, and long-lasting (Ainsworth, 2006). Bonding relationship is dyadic, bidirected (since it fulfils needs of both partners involved in the interaction- the parent and the child), but it is hierarchical since the parent is bigger, more competent than and protective toward the child (Greškovičová, 2016; Greškovičová, Szobiová, \& Zdechovanová, 2018).

There is also robust evidence that adult romantic attachment styles are empirically linked to parenting (Feeney \& Woodhouse, 2016; Priel \& Besser, 2000) with moderate negative correlations found between dimensions of anxiety/avoidance and maternal bonding toward her children (Şen \& Kavlak, 2012). Especially insecure-preoccupied and insecure-unresolved mothers reported lower bonding toward children (Wilkinson \& Mulcahy, 2010). Maternal bonding was in moderate/strong negative association with attachment avoidance (Rholes et al., 1995; Sierau, Jungmann, \& Herzberg, 2013).

But there is little evidence that transgenerational effect of attachment (what was I given, what do I share with my partner, what do I give to my newborn) within one object (mother or father) is congruent, not to mentioned that fathers are usually excluded or rather that domain of attachment is strongly matriarchal when tackling the issue of parenting.

At the same time, we notice "new" fathers who want to be present in the upbringing of their children and want to participate in everyday care activities (Kačániová, 2012). In the father-child relationship there are important these areas: the father's involvement (Lamb \& Tamis-Lemonda, 2004; Kačániová, 2012), the relationship with the child's mother (Dudová, 2008; Možný, 1990) as well as barriers that do not allow fathers to fully manifest in paternity (Potančok, 2011). Father's external bonding behavior and their involvement in daily care is supported by their early contact with the newborn (Toney, 1983; Taubenheim, 1981). Therefore, our interest was to include fathers in our research.

The bonding measurement is usually carried out in the hospital, and ours was the same. But most of the researches rely heavily on observation of parental sensitivity therefore we chose only self-reported instruments to catch the inner world of our participants and their representations. We formulated the following research questions:

RQ1 Will remembered attachment be a predictor of attachment in close relationships? RQ2 Will remembered attachment be a predictor of bonding?

RQ3 Will attachment in close relationships be a predictor of bonding?

RQ4 How is the typology in attachment in close relationships manifested in remembered attachment and bonding?

RQ5 Will there be any transgenerational effect of attachment? 


\section{DESIGN, METHODS}

Our sample consisted of 100 participants $\left(M_{\mathrm{age}}=31,11, \min 21\right.$, max 46 years; 26 men and 74 women,) from non-clinical population who recently gave birth (from 1 to 14 days postpartum). $68 \%$ of participants were married, $32 \%$ were single. More than half of the participants $(63 \%)$ had a natural childbirth, $37 \%$ gave birth by caesarean section. In $66 \%$ it was the first parity for participants, in $26 \%$ second parity, and in $8 \%$ third parity. They were approached at obstetrics and gynaecology clinic in Bratislava, Slovakia, from November 2018 till January 2019. We used 3 self-administered questionnaires: sEMBU (remembered attachment), ECR-R (attachment in close relationships), and MIBQ (bonding towards infant). The research project was approved by the Ethic committee at the obstetrics and gyneacology clinic. Subsequently, after recruiting some midwives, they distributed overall 200 questionnaires to mothers and their partners. Rate of return was $60.5 \%$. We excluded 21 questionnaires because of incompletion.

The Slovak version (Poliaková, Mojžišová, \& Hašto, 2007) of the Egna Minnen Betraffande Uppfostran- short form (My memories of upbringing, s-EMBU) by Arrindell et al. (1999) measures remembered parental rearing behaviour. 23 items are distributed into three dimensions: rejection (7 items), emotional warmth (6 items including item no. 9) and overprotection (9 items). The items are scored on a 4-point scale ranging from "no, never" to "yes, most of the time". In case of missing answers ( 7 cases- they were only children and they could not respond to items referring their siblings), we granted the participants 2.5 points on the responding scale. Summary indices are computed for each dimension regarding mother and father rearing approach. Higher summary index score indicates increased dimensions. In our research, esteem of reliability ranged between $\alpha=.798$ and .595 for the dimensions.

The Slovak version (Bieščad \& Hašto, 2010) of the ECR-R (The Experiences in Close Relationships-Revised) by Brennan et al. (1998) is a 36-item measure of adult romantic attachment style. It consists of two dimensions (avoidance and anxiety) with 18 items in each. The items are scored on a 7-point scale ranging from "strongly disagree" to "strongly agree". Average scores are computed for both dimensions. Higher average score indicates increased avoidance/anxiety. Internal consistency for avoidance was $\alpha=.865$ and for anxiety $\alpha=.773$. By combining these two dimensions, 4 types of attachment style will be created. We assigned people to these types based on the empirical median score of the dimension. A securely attached individual has a lower score than median in anxiety and avoidance, an insecurely dismissive one has a lower score than median in anxiety and a higher score than median in avoidance. Insecurely preoccupied one is vice versa and finally insecurely unresolved type scores higher than medium in both dimensions.

The MIBQ (The Mother Infant Bonding Questionnaire) by Laohapensang (1988 in Eksirinimit, 2012) measures mother-to-infant bonding. It includes 31 items divided into 6 dimensions: perception of infant features (5 items), attention and connection to the infant (6), acceptance of the infant's individuality (5), acceptance of the parent 's role (4), preparation for nurturing the infant (7) and desire to touch or hold the infant (4). The items are scored on a 5-point scale ranging from "strongly disagree" to "strongly agree". Summary indices are computed for each dimension regarding mother and father rearing approach. Higher summary index score indicates increased dimensions. In our study, there was a low estimate of reliability in the dimension acceptance of the infant's individuality. Thus, we removed item no. 16 (After childbirth I feel like I have lost some parts of my body) to correct it. Internal consistency of MIBQ questionnaire dimensions ranged $\alpha=.493$ -.801 . 
What was I given as a child, what do I share with my partner and what do I give to my newborn?

\section{RESULTS}

\subsection{Univariable analysis}

Basic descriptive statistics are displayed in table 1. Histograms and boxplots are available at authors. The distribution of bonding variables is skewed to the left, with several outliers. On the other hand, the distribution of remembered attachment variables is skewed to the right (except two dimensions that were left-skewed). In attachment in close relationships Anxiety is symmetrically distributed, while. Avoidance is skewed to the right with one outlier. Based on graphs, descriptive statistics, and normality tests we concluded that the variables except Anxiety are all non-Gaussian distributed.

Table 1.

Descriptive statistics of remembered attachment (sEMBU), attachment in close relationships (ECR-R) and bonding (MIBQ), source: authors.

\begin{tabular}{|c|c|c|c|c|c|c|c|c|c|}
\hline Remembered attachment & $\mathrm{M}$ & Mdn & Mod & SD & Min & Max & Skwe & Kurt & Range \\
\hline Father's rejection & 10.18 & 9 & 8 & 3.31 & 7 & 24 & 2.01 & 4.60 & 17 \\
\hline Mother's rejection & 10.19 & 9 & 8 & 3.08 & 7 & 22 & 1.52 & 2.33 & 15 \\
\hline Father's emotional warmth & 20.49 & 21 & 21 & 4.46 & 8 & 28 & -0.59 & 0.07 & 20 \\
\hline Mother's emotional warmth & 21.74 & 22 & 20 & 4.33 & 8 & 28 & -0.88 & 0.76 & 20 \\
\hline Father's overprotection & 18.79 & 18.79 & 15 & 3.81 & 11 & 30 & 0.33 & 0.01 & 19 \\
\hline Mother's overprotection & 20.47 & 20 & 20 & 4.14 & 11 & 30 & 0.26 & -0.37 & 19 \\
\hline Attachment in close relationships & $\mathrm{M}$ & Mdn & Mod & SD & Min & Max & Skwe & Kurt & Range \\
\hline Avoidance & 2.40 & 2.06 & 1.89 & 0.97 & 1 & 5.06 & 0.86 & -0.07 & 4.06 \\
\hline Anxiety & 2.92 & 2.89 & 2.94 & 0.83 & 1.33 & 5.17 & 0.20 & -0.25 & 3.83 \\
\hline Bonding & $\mathrm{M}$ & Mdn & Mod & SD & Min & Max & Skwe & Kurt & Range \\
\hline $\begin{array}{l}\text { Acceptance of the infant's } \\
\text { individuality }\end{array}$ & 16.13 & 17 & 20 & 3.39 & 4 & 20 & -1.06 & 1.19 & 16 \\
\hline Preparation for nurturing the infant & 28.41 & 29 & 31 & 4.84 & 10 & 35 & -1.67 & 3.65 & 25 \\
\hline Perception of infant features & 21.77 & 23 & 25 & 3.74 & 5 & 25 & -2.63 & 8.43 & 20 \\
\hline $\begin{array}{l}\text { Attention and connection to the } \\
\text { infant }\end{array}$ & 24.69 & 25 & 24 & 4.52 & 11 & 30 & -1.27 & 1.75 & 19 \\
\hline Acceptance of the parent's role & 15.77 & 16 & 20 & 3.25 & 8 & 20 & -0.20 & -0.95 & 12 \\
\hline Desire to touch or hold the infant & 17.36 & 18 & 16 & 2.80 & 5 & 20 & -2.62 & 9.01 & 15 \\
\hline
\end{tabular}

\subsection{Correlations and predictions}

Assumption of linearity between attachment variables was checked with scatterplots and it was met in all cases, if any. Then we analysed correlations and calculated a stepwise multiple regression to predict attachment in close relationships and bonding.

In remembered attachment and attachment in close relationships, Mother's emotional warmth negatively correlated with both Avoidance $(\rho=-.342)$ and Anxiety $(\rho=-0.266)$. Mother's emotional warmth also proved to be a predictor for attachment in close relationships (RQ1). It predicted Avoidance $(\mathrm{F}=10.917, \mathrm{p}<.01)$ with adjusted $\mathrm{R} 2=.091$, $(\beta=-.317 ; p=.001)$. and Anxiety $(F=5.641 ; p<.05)$ with adjusted $R 2=.045,(\beta=-.233$; $\mathrm{p}=.019)$.

Secondly, both Avoidance and Anxiety in attachment in close relationships negatively correlated with the Desire to touch or hold the infant ( $\rho=-.263 /-.235$ respectively). But we did not find any significant regression model (RQ2). 
With regard to remembered attachment and bonding, Rejection by both parents was positively correlated with Desire to touch or hold the infant $(\rho=.200, p=.046)$. Father's rejection was negatively associated with Perception of infant features $(\rho=-.219, p=.029)$. There were several correlations with Acceptance of the parent 's role: with Father's rejection $(\rho=-.219, p=.028)$, Mother's rejection $(\rho=-.285, p=.004)$, and Mother's emotional warmth $(\rho=.314, p=.001)$. Acceptance of the parent's role was predicted by remembered attachment (RQ1), namely by both Mother's emotional warmth $(\mathrm{F}=10.312$; $\mathrm{p}<.01)$, with adjusted $\mathrm{R} 2=.086,(\beta=.309 ; \mathrm{p}=.002)$, and Mother's rejection $(\mathrm{F}=6.325$, $\mathrm{p}<.05)$, with adjusted $\mathrm{R} 2=.051,(\beta=-.246, \mathrm{p}=.014)$.

\subsection{Attachment typology}

The largest part $(40 \%)$ of our participants $(\mathrm{N}=100)$ was referred to secure attachment style. Insecurely unresolved participants were closely behind (37\%). Insecurely dismissive $(11 \%)$ and preoccupied $(12 \%)$ reached almost the same occurrence. Since the variables were non-Gaussian distributed, we chose grouped median to show the differences and we used modified eta to explore relationships between attachment styles and other variables (table 2).

Table 2.

Attachment styles, source: authors.

\begin{tabular}{crrrrrr}
\hline Attachment style & Secure & Dismissive & Preoccupied & Unresolved & Eta & Eta $^{2}$ \\
\hline Father's rejection & 8.7 & 10.0 & 9.3 & 9.6 & .127 & .016 \\
\hline Mother's rejection & 9.0 & 9.0 & 9.0 & 9.7 & .119 & .014 \\
\hline Father's emotional warmth & 22.3 & 20.5 & 21.5 & 20.4 & .215 & .046 \\
\hline Mother's emotional warmth & 24.4 & 20.0 & 22.7 & 20.9 & .333 & .111 \\
\hline Father's overprotection & 18.3 & 19.7 & 19.0 & 18.8 & .116 & .013 \\
\hline Mother's overprotection & 19.9 & 20.0 & 20.3 & 21.0 & .098 & .010 \\
\hline Perception of infant features & 22.5 & 21.5 & 23.0 & 22.9 & .156 & .024 \\
\hline $\begin{array}{c}\text { Attention and connection to the } \\
\text { infant }\end{array}$ & 25.3 & 24.3 & 27.3 & 25.0 & .175 & .031 \\
\hline $\begin{array}{c}\text { Acceptance of the infant's } \\
\text { individuality }\end{array}$ & 16.3 & 17.5 & 17.4 & 16.4 & .185 & .034 \\
\hline Acceptance of the parent's role & 17.0 & 15.0 & 13.8 & 15.1 & .213 & .046 \\
\hline Desire to touch or hold the infant & 18.3 & 18.0 & 18.5 & 17.0 & .311 & .096 \\
\hline Preparation for nurturing the infant & 30.0 & 28.8 & 27.7 & 29.3 & .268 & .072 \\
\hline \hline
\end{tabular}

The strongest relationship between attachment styles and bonding was a moderate relationship with Desire to touch or hold the infant $(\eta=.311, \eta 2=.096$ with $9,6 \%$ variance), (RH3). The strongest relationship between attachment styles and remembered attachment was with Mother's emotional warmth $(\eta=.333, \eta 2=.111$ with $11.1 \%$ variance).

\section{DISCUSSION/CONCLUSION}

Transgenerational transmission is an intriguing area to study. We defined so-called transgenerational effect of attachment that stands for one-object-attachment-representation transmission and we explored it with three self-reported tools (for remembered attachment, attachment in close relationships, and bonding). We formulated five research questions. 


\subsection{Remembered attachment and attachment in close relationships}

We found out that the more avoidant and anxious participants were, the less mother's emotional warmth they felt. This relationship was moderate, and it is in accordance with other researchers (Priel \& Besser, 2000; Rozvadský Gugová et al., 2014). Mother's emotional warmth was actually also a predictor of both anxiety $(5 \%)$ and avoidance $(9 \%)$ in close relationships (RQ1), that is also in line with other researches (Priel \& Besser, 2000; Rholes et al., 1995).

When we preformed attachment typology, we explored a moderate relationship between styles and mother's emotional warmth with securely attached individuals feeling most emotional warmth by their mother's and insecure-dismissive ones feeling least (RQ4). Such a concordance of attachment styles has been confirmed by previous research (Behrens et al., 2016; Bretherton \& Munholland, 2008; Feeney \& Woodhouse, 2016) where insecurely attached individuals negatively perceived their parents (Rholes et al., 1997).

\subsection{Remembered attachment and bonding}

The research has shown that parent representations are empirically linked to parenting (Behrendt et al., 2016; Feeney \& Woodhouse, 2016; Van Ijzendoorn, 1995) with a moderate relationship between parent attachment representations and his/her sensitivity (Feeney \& Woodhouse, 2016). In our research the most important dimension in bonding regarding remembered attachment was acceptance of the parent's role which was linked to mother's emotional warmth and rejection by both parents. The more mother's emotional warmth participants felt during their upbringing, the more they accepted their parent's role. On the other hand, if the participants felt rejected by either their mother or father, they were less able to accept their own parent's role. We also confirmed the prediction model mother's emotional warmth $(9 \%)$ and rejection $(5 \%)$ were predictors of how women or men accepted their role as being a parent (RQ2).

Acceptation of the parent's roVle seems very important. Parent role and its attainment comprises of two processes- attainment of parent's identity and role competency (Barnard \& Solchany, 2002). Attainment is indeed a slow process that starts months before childbirth and is usually anchored at 1 year postpartum. Moreover, self-efficacy theory states that competent people are more likely to act as competent. So, we can assume that if a parent accepts the parent's role, s/he feels more competent and therefore acts more competently in parenting as well. Parental competence was a major predictor of parental bonding for various groups of parents (low or high risk, women, or their partners) (Mercer \& Ferkehch, 1990). Combination of anxiety, parental competence, received support, fetal attachment, marital status, and relationship with own mother as a child can explain $41 \%$ of variance of bonding early postpartum (Mercer \& Ferkehch, 1990).

\subsection{Attachment in close relationships and bonding}

Parent representations/adult romantic attachment styles are recognizably associated with parenting (Benoit \& Parker, 1994; Feeney \& Woodhouse, 2016; Priel \& Besser, 2000; Şen \& Kavlak, 2012; Van Ijzendoorn, 1995) and the same was in our research, even though we found only weak negative relationships and only with one of the bonding dimensions (desire to touch or hold the infant). Consequently, regression analysis did not confirm prediction power of attachment in close relationships to bonding (RQ3).

When finding overlapping areas between attachment typology and bonding (RQ4), individuals with secure attachment style most accepted their parent's role and were least neglectful in preparing for child nurture. On the contrary, insecure-dismissive individuals were least prepared for the parent's role. This can be reflected in closeness to children when 
mothers with dismissive attachment style feels more distant from their child (Rholes et al., 1995). Moreover, individuals with preoccupied attachment style mostly perceived the infant's features, but they least accepted their parent's role. Unresolved attachment style was characterized with unacceptance of infant's individuality. The most noted associations between attachment styles and bonding were two- moderate relationship with desire to touch and hold the baby (physical closeness toward the infant) and weak relationship with preparation for nurturing the infant (consciously getting ready for the infant's coming and setting up for its needs). We can assume that the MIBQ does not tap the three compounds of bonding- behavioral, affective and cognitive compounds (Greškovičová, 2016) and it misses one of the very important compound- affective one that is intensely studied when dealing with parent-to-infant relationship (Behrens et al., 2016; Brockington, Fraser, \& Wilson, 2006; Brockington et al., 2001).

\subsection{Transgenerational effect}

Let's now consider transgenerational effect (RQ5) from the correlations and predictions that we calculated. When we continue the rails of attachment, we can trace back that emotional warmth shown by mother has prediction power to attachment in close relationship (avoidance in $9 \%$ and anxiety in 5\%) which in turns correlated with the wish for physical contact with own infant (desire to touch or hold the infant). Furthermore, the emotional warmth together with rejection by mother are predictors of acceptance of own parent's role in bonding in $8 \%$ and $5 \%$ respectively. We can conclude that emotional warmth shown by own mother that is remembered by an adult is further transmitted and expressed in attachment in partnership and then also in bonding.

\subsection{Limits and future research}

We see several limits among which self-reported instruments, new questionnaire MIBQ in Slovak language, relatively big age range of our participants, smaller sample of men are the most serious ones. Furthermore, we wanted to include fathers in parenting issue, but fathers of our participants are still "missing" in our results. We can assume that mothers hold the top and strong position in attachment pyramid (Brisch, 2011). We also noted that during participants recruit men were not so willing to participate and when so, their feedback was also negative. They themselves saw bonding as being a kingdom solely for women and they did not feel comfortable to answer the bonding questions. We see here a huge misconception in the society even though that "new" fathers are "real" (Kačániová, 2012). Therefore, we should support men in being more involved and underline the benefits of bonding, we should empower them in their relationships with children.

Transgenerational effect of attachment is difficult to capture and our methods were potentially not the best ones in doing so. It looks like the questionnaire sEMBU for remembered attachment taps very important areas of parenting but still does not cover whole area of remembered attachment toward parents because two dimensions- rejection and hyperprotectivity slipped out from the important results and were not differentiative in attachment typology. We can also assume that the MIBQ does not tap the three compounds of bonding- behavioral, affective, and cognitive compounds (Greškovičová, 2016) and it misses necessary affective one. In the future, we would therefore like to match the instrument assessing attachment and bonding and thus to have comparable results for parental behavior, partnership, and bonding. We should deliberate whether other concepts such as psychological types /traits (Lisá, 2017; Lisá \& Kališ, 2019) or parenting styles (Dvorská, 2017) are not involved in the manifested/ measured behaviours too. 


\subsection{Highlights and conclusion}

Despite limits, we consider our research to be important in slightly clarifying attachment transmission and transgenerational effect of attachment within one object. What was I given, what do I share with my partner and what do I give to my newborn are very important questions in everyday life of parents. Via attachment theory perspective, we expected to gradually unwind an attachment thread- starting with remembered attachment, then continue with attachment in close relationships and ending with bonding. Remembered attachments did manifest in attachment in close relationship and bonding separately, but we missed the connection between attachment in close relationship and bonding. Based on our results and interpretations, we conclude that namely mother's emotional warmth in remembered attachment seems to be important and helpful in romantic relationships as well as in bonding (accepting the parent's role). Mothers usually stand on a pedestal in the pyramid of attachment figures and it seems that in our research it was not differently. Mothers are primary caregivers and therefore are important providers of emotional warmth.

\section{REFERENCES}

Ainsworth, M. D. S. (2006). Attachments and other affectional bonds across the life cycle. In C. M. Parkes, J. S. Hinde, \& P. Marris (Eds.), Attachment Across the Life Cycle (pp. 33-51). London, England: Routledge.

Arrindell, W. A., Sanavio, E., Aguilar, G., Sica, C., Hatzichristou, C., Eisemann, M., Recinos, L. A., Gaszner, P., Peter, M., Battagliese, G., Kállai, J., \& van der Ende, J. (1999). The development of a short form of the EMBU: Its appraisal with students in Greece, Guatemala, Hungary and Italy. Personality and Individual Differences, 27(4), 613-628. https://doi.org/10.1016/S0191-8869(98)00192-5

Barnard, K. E., \& Solchany, J. E. (2002). Mothering. In M. H. Bornstein (Ed.), Handbook of parenting (Vol. 3, pp. 3-25). Mahwah, NJ: Erlbaum.

Bartholomew, K., \& Horowitz, L. M. (1991). Attachment Styles Among Young Adults: A Test of a Four-Category Model. Journal of Personality and Social Psychology, 61(2), 226-244. https://doi.org/10.1037/0022-3514.61.2.226

Behrendt, H. F., Konrad, K., Goecke, T. W., Fakhrabadi, R., Herpertz-Dahlmann, B., \& Firk, C. (2016). Postnatal Mother-to-Infant Attachment in Subclinically Depressed Mothers: Dyads at Risk? Psychopathology, 49(4), 269-276. https://doi.org/10.1159/000447597

Behrens, K. Y., Haltigan, J. D., \& Bahm, N. I. G. (2016). Infant attachment, adult attachment, and maternal sensitivity: Revisiting the intergenerational transmission gap. Attachment and Human Development, 18(4), 337-353. https://doi.org/10.1080/14616734.2016.1167095

Benoit, D., \& Parker, K. C. H. (1994). Stability and Transmission of Attachment across Three Generations. Child Development, 65(5), 1444-1456. https://doi.org/10.1111/j.1467-8624.1994.tb00828.x

Bieščad, M., \& Hašto, J. (2010). Diagnostikovanie typov vztahovej väzby (attachment) v dospelosti s použitím nástrojov dostupných $\mathrm{v}$ našich podmienkach [Assessment of the adult attachment using the questionnaires available within the Slovak and Czech area]. Psychiatrie, 14(2), $68-74$.

Birnbaum, G. E. (2016). Attachment orientations, sexual functioning, and relationship satisfaction in a community sample of women: Journal of Social and Personal Relationships, 24(1), 21-35. https://doi.org/10.1177/0265407507072576

Birnbaum, G. E., Reis, H. T., Mikulincer, M., Gillath, O., \& Orpaz, A. (2006). When sex is more than just sex: Attachment orientations, sexual experience, and relationship quality. Journal of $\begin{array}{llll}\text { Personality and Social } & \text { Psychology, 929-943. }\end{array}$ https://doi.org/10.1037/0022-3514.91.5.929 
Bowlby, J. (2010). Vazba. Teorie kvality raných vztahů mezi matkou a ditětem [Attachment. Theory of early bond quality between mother and baby]. Praha, Česko: Portál.

Brennan, K. A., Clark, C. L., \& Shaver, P. R. (1998). Self-report measurement of adult attachment: An integrative overview. In J. A. Simpson \& W. S. Rholes (Eds.), Attachment Theory and Close Relationships (p. 46-76). New York, NY: Guilford Press.

Bretherton, I., \& Munholland, K. A. (2008). Internal working models in attachment relationships: Elaborating a central construct in attachment theory. In J. Cassidy \& P. R. Shaver (Eds.), Handbook of Attachment: Theory, Research and Clinical Applications (2 ${ }^{\text {nd }}$ ed., pp. 102-127). London, England: Guildford Press.

Brisch, K. H. (2011). Bezpečná vzt’ahová väzba. Attachment v tehotenstve a prvých rokoch života. [Secure attachment. Attachment in pregnancy and first years of life]. Trenčín, Slovakia: Vydavatel'stvo F.

Brockington, I. F., Fraser, C., \& Wilson, D. (2006). The Postpartum Bonding Questionnaire: A validation. Archives of Women's Mental Health, 9(5), 233-242. https://doi.org/10.1007/s00737-006-0132-1

Brockington, I. F., Oates, J., George, S., Turner, D., Vostanis, P., Sullivan, M., Loh, C., \& Murdoch, C. (2001). A screening questionnaire for mother-infant bonding disorders. Archives of Women's Mental Health, 3(4), 133-140. https://doi.org/10.1007/s007370170010

Butzer, B., \& Campbell, L. (2018). Adult attachment, sexual satisfaction, and relationship satisfaction: A study of married couples. Personal Relationships, 15(1), 141-154.

Cobb, R. J., Davila, J., \& Bradbury, T. N. (2001). Attachment Security and Marital Satisfaction: The Role of Positive Perceptions and Social Support. Personality and Social Psychology Bulletin, 27(9), 1131-1143. https://doi.org/10.1177/0146167201279006

Crowell, J. A., Treboux, D., \& Waters, E. (2002). Stability of attachment representations: The transition to marriage. Developmental Psychology, 38(4), 467-479. https://doi.org/10.1037//0012-1649.38.4.467

Dvorská, B. (2017). Rodičovská výchova a jej dopad na správanie detí [Parent styles and its impact on children's behaviour]. In L. Pašková (Ed.), Prevencia agresie v kontexte mentálneho zdravia: zborník príspevkov z medzinárodnej vedeckej konferencie [Prevention of aggression in the context of mental health: conference proceeding from international scientific conference] (pp. 73-78). Banská Bystrica, Slovakia: Univerzita Mateja Bela, Pedagogická fakulta.

Dudová, R. (2008). Otcovství po rozchodu rodičovského páru [Fatherhood after the break-up of the parent couple]. Praha: Česká republika: Sociologický ústav AV-ČR.

Eksirinimit, T. (2012). A longitudinal evaluation of Kangaroo Care for preterm infants in Thailand (Doctoral dissertation, Flinders University. School of Nursing \& Midwifery). Retrieved from https://theses.flinders.edu.au/view/d11d8efe-c5d0-4d92-8009$585 \mathrm{cc} 4 \mathrm{c} 7 \mathrm{~d} 518 / 1$

Feeney, B. C., \& Woodhouse, S. (2016). Caregiving. In J. Cassidy \& P. R. Shaver (Eds.), Handbook of Attachment: Theory, Research, and Clinical Applications (pp. 827-851). London, England: Guilford Press.

Greškovičová, K. (2016). Bonding a attachment v kontexte rodičovstva [Bonding and attachment within parenthood]. [Dissertation thesis, Paneuropean University]. Retrieved from https://opac.crzp.sk/?fn=detailBiblioForm\&sid= 08B0A201CAF64A608886C6D1F450

Greškovičová, K., \& Sakačová, Z. (2019). Attachment and love in single and coupled young adults. Comparative European Research 6(2), 181-184. Retrieved from https://www.sciemcee.org/library/proceedings/cer/cer2019_proceedings02.pdf

Greškovičová, K., Szobiová, E., \& Zdechovanová, B. (2018). Bonding k diet’at’u u žien a mužovIndividuálna a párová analýza [Bonding towards infants in women and men- individual and pair analysis]. In L. Sabová (Ed.), Psychologica 47 (p. 39-46). Bratislava, Slovakia: Stimul.

Hamilton, C. E. (2000). Continuity and Discontinuity of Attachment from Infancy through Adolescence. Child Development, 71(3), 690-694. https://doi.org/10.1111/1467-8624.00177

Hennelová, K. (2014). Biodromal psychology. Nitra, Slovakia: ForPress Nitrianske tlačiarne.

Kačániová, L. (2012). Matky, otcovia a zamestnanie [Mothers, fathers, and jobs]. In A. Heretik \& E. Rošková (Exe. Eds.), Psychologica XLI (p. 371-385). Bratislava, Slovakia: Stimul. 
Transgenerational Effect of Attachment What was I given as a child, what do I share with my partner and what do I give to my newborn?

Lamb, M.E., \& Tamis-Lemonda, C.S. (2004). The role of the father: An introduction. In M.E. Lamb (Ed.), The Role of the Father in Child Development ( $5^{\text {th }}$ ed., pp.1-31). John Wiley \& Sons.

Lisá, E. (2017). Analysis of personality traits among psychological types. Ad Alta, 7(2), 118-122.

Lisá, E., \& Kališ, M. (2019). The psychometric characteristics of the Hexaco-100 questionnaire used in the selection and non-selection situation. Work and Organizational Psychology 2019: Proceedings of the 18th International Conference, 144-153.

Mercer, R. T., \& Ferkehch, S. L. (1990). Predictors of parental attachment during early parenthood. $\begin{array}{llll}\text { Journal of } & \text { Advanced } & \text { Nursing, } & \text { 15(3), 268- }\end{array}$ https://doi.org/10.1111/j.1365-2648.1990.tb01813.x

Mikulincer, M., \& Shaver, P. R. (2007). Attachment in adulthood: Structure, dynamics, and change. New York, NY: Guilford Press.

Mikulincer, M., \& Shaver, P. R. (2008). Adult attachment and affect regulation. In J. Cassidy \& P. R. Shaver (Eds.), Handbook of Attachment. Theory, Research, and Clinical Applications (pp. 503-531). London, England: Guildford Press.

Možný, I. (1990). Moderní rodina: Mýty a skutečnosti [Modern family: Myths and reality.]. Brno, Česká republika: Blok.

Pietromonaco, P. R., Barrett, L. F., \& Powers, S. I. (2006). Adult Attachment Theory and Affective Reactivity and Regulation. In D. K. Snyder, J. Simpson, \& J. N. Hughes (Eds.), Emotion regulation in couples and families: Pathways to dysfunction and health. (pp. 57-74). American Psychological Association. https://doi.org/10.1037/11468-003

Poliaková, M., Mojžišová, V., \& Hašto, J. (2007). Skrátený dotazník zapamätaného rodičovského správania ako výskumný a klinický nástroj s-EMBU [Shortened inventory for memories of parental rearing behaviour as a research and clinical instrument]. Psychiatria-psychoterapiapsychosomatika, 14(2-3), 79-88.

Potančok, J. (2011). Bariéry otcovských tranzícií [Barriers within fatherhood transition]. Sociální studia, 4, 29-45.

Priel, B., \& Besser, A. (2000). Adult attachment styles, early relationships, antenatal attachment, and perceptions of infant temperament: A study of first-time mothers. Personal Relationships, 7(3), 291-310. https://doi.org/10.1111/j.1475-6811.2000.tb00018.x

Rholes, W. R., Simpson, J. A., Blakely, B. S., Lanigan, L., \& Allen, E. A. (1997). Adult Attachment Styles, the Desire to Have Children, and Working Models of Parenthood. Journal of Personality, 65(2), 357-385. https://doi.org/10.1111/j.1467-6494.1997.tb00958.x

Rholes, W. S., Simpson, J. A., \& Blakely, B. S. (1995). Adult attachment styles and mothers' relationships with their young children. Personal Relationships, 2(1), 35-54. https://doi.org/10.1111/j.1475-6811.1995.tb00076.x

Rozvadský Gugová, G., Heretik, A., \& Hajdúk, M. (2014). Psychometric properties of the Slovak version of Experiences in Close Relationships- Revisited (ECR-R) on general adult sample. Studia Psychologica 56(1), 37-52.

Şen, S., \& Kavlak, O. (2012). Transgenerational attachment in Manisa, Turkey. Contemporary Nurse, 41(1), 126-132. https://doi.org/10.5172/conu.2012.41.1.126

Sierau, S., Jungmann, T., \& Herzberg, P. Y. (2013). First-time parenthood under socially disadvantaged conditions: Linking caregivers' experiences of avoidance and relationship satisfaction with feelings of closeness to the infant. Journal of Family Studies, 19(2), 196-206. https://doi.org/10.5172/jfs.2013.19.2.196

Sundin, E., Wiberg, B., \& Eklöf, H. (2002). Change and stability of attachment from childhood to early adulthood. Umea Psychology Reports, 2, 1-9.

Taubenheim, A.M. (1981). Paternal-infant bonding in the first-time father. Journal of Obstetric, Gynecologic, \& Neonatal Nursing, 10(4), 261-264.

Toney, L. (1983). The effects of holding the newborn at delivery on paternal bonding. Nursing Research, 32(1), 16-19.

Van Ijzendoorn, M. H. (1995). Adult attachment representations, parental responsiveness, and infant attachment: A meta-analysis on the predictive validity of the adult attachment interview. Psychological Bulletin, 117(3), 387-403. https://doi.org/10.1037/0033-2909.117.3.387 
Verhage, M. L., Schuengel, C., Madigan, S., Pasco Fearon, R. M., Oosterman, M., Cassibba, R., Bakermans-Kranenburg, M. J., \& Van Ijzendoorn, M. H. (2016). Narrowing the transmission gap: A synthesis of three decades of research on intergenerational transmission of attachment. Psychological Bulletin, 142(4), 337-366. https://doi.org/10.1037/bul0000038

Waters, E., \& Cummings, E. M. (2000). A secure base from which to explore close relationships. Child development, 71(1), 164-172. https://doi.org/10.1111/1467-8624.00130

Waters, E., Merrick, S., Treboux, D., Crowell, J., \& Albersheim, L. (2000). Attachment Security in Infancy and Early Adulthood: A Twenty-Year Longitudinal Study. Child Development, 71(3), 684-689. https://doi.org/10.1111/1467-8624.00176

Wilkinson, R. B., \& Mulcahy, R. (2010). Attachment and interpersonal relationships in postnatal depression. Journal of Reproductive and Infant Psychology, 28(3), 252-265. https://doi.org/10.1080/02646831003587353

\section{AUTHORS' INFORMATION}

Full name: Katarína Greškovičová, Mgr., PhD.

Institutional affiliation: Institute of Applied Psychology, Faculty of Social and Economic Sciences, Comenius University in Bratislava

Institutional address: Mlynské luhy 4, Bratislava, 82105, Slovakia

Email address: katarina.greskovicova@uniba.sk

Short biographical sketch: Katarina is a psychologist that earned her master's degree in psychology at the Comenius University in Bratislava. Then she pursued her studies and finished her PhD. study at the Pan-European University in Bratislava where she dedicated to study attachment and bonding within parenthood. Currently, she works as an assistant professor at the Faculty of Social and Economic Sciences, Comenius University. Her research interests cover various areas including peri- and post-natal period, bonding, and attachment in different settings (parenthood, partnership, workplace, health area). In 2018, she represented Slovakia as a member of the commission in the international project COST Action BIRTH 1405 "Building Intrapartum Research Through Health - an interdisciplinary whole system approach to understanding and contextualizing physiological labor and birth (BIRTH)". She is National Coordinator for Slovakia in the international project Babies Born Better (www.babiesbornbetter.org).

Full name: Kristína Mrázková

Institutional affiliation: Institute of Applied Psychology, Faculty of Social and Economic Sciences, Comenius University in Bratislava

Institutional address: Mlynské luhy 4, Bratislava, 82105, Slovakia

Email address: kristina.mrazkova@uniba.sk

Short biographical sketch: Kristina started her study at the Faculty of Psychology at the University of New York in Prague. After moving back to Slovakia, she continued her studies in psychology at the Faculty of Psychology at the Pan-European University where she finished her master's degree. After school she worked as a behavioural therapist with autistic children aged from 2 to 10 . Her scientific focus includes various areas, mainly attachment and its connections with other interesting variables, such as sexual behaviours, remembered attachment, bonding, organizational behaviour and effectiveness. She is currently studying PhD. at the Faculty of Social and Economic Sciences at the Comenius University in Bratislava. 